\title{
LANGUAGE INEQUALITY AND THE USE OF STANDARD
}

\section{LANGUAGE}

\section{Prof. Ass. Flamur SHALA}

Prizren University “UKSHIN HOTI, Faculty of Philology, flamur.shala@uni-prizren.com

\section{Article history:}

Accepted 15 February 2019

Available online 30 April 2019

Keywords:

Language Competence,

Standard Language,

Language Inequality

Language Deficit,

Restricted Code

Elaborated Code.

A b s t r a c t

This paper deals with linguistic inequality and the use of standard language. Language inequality has a wide and multifaceted meaning with several interpretations. It should be noted that the habits of informal use of the language do not define all inequality because the same user in another circumstance may use the language standard and manage to indicate a certain degree of use of the language. From the research with students of Albanian language, it turns out that these students, starting from the first year of the studies, show the efforts, the ability and the skills of using the linguistic standard despite a linguistic conformism. Linguistic individuality highlights the linguistic inequality.
\end{abstract}

Language inequality has linguistic or limited language deficits on written and speech discourse. Meanwhile, the text sublimates the individual skills of writing, brainstorming, text planning, linguistic coherence and cohesion, according to an elaborate linguistic code. Furthermore, we see that language inequality is relative, because everyone who writes or speaks, under certain conditions, has his / her linguistic competence and individuality. In my research on students` texts are noticed some elements dealing with linguistic inequality and use standard language.

\section{Language inequality and the use of standard language}

The question being raised. - Language competence, linguistic conformism and the use of standard language by speakers and writers are different. The degree of linguistic conformation (Shala Perla, 2018) and the use of the standard language of Albanian language students, based on their written and interpreted texts, is also different. In this context, one of the issues for study is language inequality.

The students of the first year of the Albanian Language and Literature department were set an assignment in the subject of language culture: to read, to learn and to write about the topic "the use of standard Albanian language on Albanian TV shows". As I rely on the data of this research to elaborate and draw conclusions about linguistic conformism in relation to the use of standard language, I have also relied on the same data source for language inequality.
On the topic "Using standard Albanian language on Albanian TV shows", students read and learned for a week, from one weeks exercises class to the next week, a week later. They who had studied managed to write about the topic within one lesson class. The following week, the assessment was made on the use of the language standard in their texts, linguistic coherence and cohesion. In the third and fourth classes, after a week, the same texts were read and interpreted aloud. Each student read and interpreted their own text. The debate on the use of standard language in written lectures and speech discourse was focused on linguistic competence (Memushaj 2008, p. 86.), language conformism (Shkurtaj 2009, p. 197), linguistic individualism (Shkurtaj 2008, 194, p. 195) and linguistic inequality (Hadson 2002, p. 226). These indicators are interdependent. This research is more about language inequality.

Language competence and inequality. - Language competence refers more to Noam Chomsky. (Hadson 2002, p. 244.). Performance is not a direct reflection of language competence, because in the spoken discourse (Sosyr 1977, p. 58.), the 
registration marks deviations from the rules and from the performance data derives the "subordinate" system of the rules that are owned by the speaker-listener. Unlike Sosyr, where Langue (Sosyr 1977, p. 44.) is the language in its system. The competence, always according to Chomsky, is the ability of the ideal speaker-listener to master the language, as well as its system. The answer to language competence and performance (Memushaj, 2008, p. 86.), referring to the concept itself, raises even more the question of what is not covered from the language competence. Lack of language is out of competence. To this extent linguistic absence can be called the first step of language inequality.

Being the first step, language absence is a kind of linguistic inequality. Language inequality has a wide and multifaceted meaning, with several interpretations. Insufficient reading in new social contexts and the lack of speaking activity of individual speakers increases language inequality in relation to those who read, write and speak (explain, elaborate, interpret). Language competence as the ability to master the language in its system is not enough to read nor speak the individual's activity, without relating to normative language learning and language learning in the entirety of its variations.

The habit of informal language use do not define all inequality because the same speaker in another circumstance can use the language standard and reach a high degree of linguistic competence. According to this measure, students of Albanian language who in the first year, besides a certain degree of language possession in its written and spoken system, also exhibit linguistic inequality.

Language inequality and the use of standard language are related to:

- Normative language learning; spelling, reading, and righteousness;

- Normative language learning, the massiveness of variations and language inequality;

- Language Culture and Language Inequality;

- Rate of use of language standard and language inequality;

- Limited and elaborate language code;

- Language Individuality and Language Inequality;

- Context (contextualization) and linguistic inequality; linguistic conformation and inequality.

- Language Conformity and Language Inequality in Written Texts.
Normative Language Learning: the correct spelling, reading and pronunciation. - Normative language instruction is the study of language system, is the study of the use of standard written and spoken Albanian norms. Regarding these two fundamental realizations, R. Ismajli has raised the question that the differences between written and spoken Albanian are two codes or realizations of a more general code? (Ismajli 2003, p. 155.).

The written language of the students, based on the normative and systemic language learning, expresses a degree of language competence, the use of spelling with differences from text to text. The use of the standard language spelling represents only a degree of linguistic culture, which is not realized in the same way.

The difference between linguistic accomplishments is also noticeable when using the spoken language according to normative teaching. The standard (spoken) language of a student, with the utmost care for the implementation of language norms, in most cases, achieves a degree of expression according to normative teaching, distinguishing from the other, according to the pronunciation and the prosody (metrics). In these cases, when using the spoken language is noticed a degree of language competence, according to pronunciation, but the differences are evident.

Although linguistic conformism (Shkurtaj 2009, p. 197.) on the one hand and the standard rate of Albanian language learning have worked, on the other hand, the differences remain. The basis of these differences is the different spoken language from the point of view of dialectal nuances and from the sociolinguistic aspect of linguistic individualism.

Normative language learning, the massiveness of variations and language inequality. - Using dialect of language and linguistic individuality are some of the factors that affect the differences between spoken language. Neither normative language learning nor linguistic conformism completely distorts the differences. Normative language learning and the massiveness of variations point to language inequality in relation to the degree of standard language use of each student. Variations are expressions of the linguistic individualism of the speaker, which imply the personal character of individual human speech (Shkurtaj 2009, p. 194.). The linguistic individuality in the totality of variations cannot function without a minimum of consonance and linguistic conformism with the social environment (Shkurtaj 2009, p. 194). This minimum of conformism would imply a minimum of normative language instruction and the entirety of variations that uncover and remain linguistically unequal.

Language Culture and Language Inequality. - Issues related to language inequality are also related to crystallization of literary norms, "not as dialectical problems but as problems of language culture" (Lafe 1983, p. 101.). Language-related issues have 
attracted and still attract the attention of Albanian linguistics to their solution in the development of language and literary crystallization (Lafe 1983, p. 101.). In this context, the differences appear in the application of the morphological principle of the words of the Albanian language such as the use of the undefined $\ddot{e}$, the use of plural names and irregular plurality. Also, the use of polysemistic words (Baylon \& Mignot, 2004, p. 17.), where the meaning of a word, being used unnecessarily in certain contexts, reveals language lack, thus revealing language inequality.

Missing normative language lesson, its system and the use of standard Albanian, written and spoken norms, highlight the differences that mark language inequality.

The absence of normative language instruction, on its system and on the standard Albanian language use, in the spoken and written form, reveals the differences which mark linguistic inequality.

Rate of use of language standard and language inequality. - The use of language standard by students is an effort to apply spelling alongside the daily language learning. In addition to the differences in text and style planning, linguistic inequality in standard use also occurs in some grammatical terms of words as well as in syntactic connections. In the 33 evaluated texts, for the same topic, the introductory paragraph is different and in some cases the text begins with a finding or analytical elaboration of the topic in question. Standard deviations point to certain forms of words and improper links of words in sentences. Inequality also results from language learning, with unequal dedication. Thus, deviations from the norm on the one hand and the correct use of the linguistic standard, on the other hand, reveal the limited and elaborate linguistic code.

Limited and elaborate language code. - The text written with concentration sublimates the individual ability and skills of writing, linguistic coherence and cohesion, the degree of language learning. On the contrary, through it appear the stagnation, the lack of language skills. So, the limited code or linguistic deficit emerges (Hadson 2002, p. 246.).

In spite of the idea of "Using standard language in Albanian TV shows", the texts are conceived, more or less, they differ from the use of the language ( the form) and the way of explication (the content). Based on the above parameters, such as normative learning, language learning, the massiveness of variations and the degree of use of the language standard, reading and evaluating the texts is a limited and elaborate language code, according to the texts. Here, the limited code relates to the unequal recognition of particular units (Hadson 2002, p. 246.), relevant to the text. Thus, the limited code refers to a kind of linguistic deficit of language use according to normative and stylistic learning. The limited code is the lack of language tools needed for a text with a certain topic and content. In student texts, language use shows the degree of normative language learning that discovers restricted and elaborate language code. This is the linguistic inequality associated with the normative level of language learning.

Language Individuality and Language Inequality. - As stated above, Hadson says that different language units can be used to express more or less the same meaning in different instances of language use. In the textbooks of the same pre-arranged subject we find a different linguistic arrangement, essentially with almost the same meaning. We find texts activated differently from one another, to the contextualization process, so to reconstruct the recipient's goals identical to the target recipients. Language inequality here, however, is concerned with the linguistic individuality and degree of linguistic conformity, as well as with the individual language competence and culture in written discourse and speech discourse.

The use of "different" language units to express the same meaning is in the nature of linguistic communication. The different use of language units is more common in spoken discourse, generally. Anyway, it also comes down to the written discourse. Different use of language units for the same meaning does not escape the use of units according to language standard. The measurement in each of the texts gives the language-related results for the standard, the elaborated language code, the language, the language deficit, and the lack of language tools, in the limited language code.

In the texts used for standard measurements of the standard language of the students, we find that the same subject can be written differently, can be written with standard language of a certain level. Fulfilling the use of standard language is a continuous requirement. It is not unnatural to attempt and therefore it is possible to use the language standard of the level of learning that the student has achieved. It is not just a standard language learning factor, though it is the main factor. Another factor is the textual planning on the subject and the stylistic fulfillment of the text.

In these texts there is generally an "elaborate code" dependent by the situation, by the type of text. The situation is that the student writes the text of the argumentative type and gives his opinion using the standard language. Each has an elaborate code with its own linguistic individuality, different dependent from the text.

Students come from language circles, not a school, with different interests, with different background preparation and with different linguistic individualities. They associate "linguistic conformism" with the use of standard language. During this use, their language individualities are modeled and adapted. Language Modeling (Shkurtaj 2009, p. 199.) occurs from standard language learning, requirements and school needs for "linguistic 
conformism" (Shkurtaj 2009, p. 201.) based on the use of standard language. Language modeling and adaptation or conformism does not avoid linguistic inequality.

Linguistic inequality has its own linguistic, sociolinguistic and psycholinguistic side, in spoken and written discourse. The appearance of linguistic individuality and language inequality in written discourse is not the same as the language inequality in speech discourse. Measurement of language inequality in these relationships is derived from the texts, on the one hand and from reading and interpreting them, on the other hand developed in a process within exercises classes. The results derive from the measurement of the use of the linguistic standard as a part of linguistic culture and the emergence of language inequality in written discourse and speech discourse. The measurement is not supposed to be completed. Measurement has started with the firstyear students with tangible indicators and measurements of language inequality in the discourse of written texts and speech discourse, according to the correct pronunciation of the languageword units and the use of proxies.

Context, contextualization and language inequality. - The linguistic context (Rugova \& Sejdiu Rugova 2015, p. 39-40.), as an implicit quote of the text, is new in a social communication context (Islamaj, 2014, p. 117-126.). Hence, linguistic change occurs with social change to reflect new social-linguistic contexts within language communication. In other words, the standard word of the standard language was not used at the time of the Albanian Language Scripting Congress and many years after the Congress, when in some other languages it had long stood; at least it was not used with the meaning that is used today. Thus, the standard word, standard language, standard norm, linguistic standard, in textbooks are written with the meaning of the literary language, the term that was used, is used and there are linguists who prefer it today.

Contextualization is reconstruction by the sender's target recipient and it results from the text activation process by linking it to a context of use. This activation of text associated with a context of use would now be called discourse. Language inequality results from the different activation of the text on the same topic of each student. Activating the text reveals the degree of language competence, coherence and language cohesion and the elaborated language code (Hadson 2002, pp. 245.) and the same as the lack of language tools (Hadson 2002, p. 245.), the limited code and the linguistic deficit (Hadson 2002, p. 246.).

Language Conformity and Language Inequality in Written Texts. - Language inequality, as mentioned above, appears in the written discourse and speech discourse. The text sublimates the ability and individual skills of writing, brainstorming, textual planning, coherence and linguistic cohesion, the degree of language learning, and vice versa, through which it shows latencies, lack of language skills, limited code a linguistic deficit (Hadson 2002, p. 246.). Through the written discourse, more than anything else comes up with the language culture of the individual. Generally, depending on education as a requirement of the education system and individual sentiment, the desire to master the language better, the students reveal the level of use of standard language including the measured linguistic inequality. Even when language use by students is within the "linguistic conformism" and conditionally accurate, even then there is a language inequality. As in other cases, the inequality results from linguistic individualism to express the same meaning.

Hadson (2002, p. 57.) mentions language inequality even when "The same person can use very different linguistic units to express more or less the same meaning in different instances" and adds that "the concept of dialect logically cannot be extended as far as to include such a variation "(Hadson 2002, p. 57.). The linguistic, morphological, syntax and stylistic aspect, the individual language processing code, and the standard rate teaching of the language planning in education (Holmes 2015, 138.) on the one hand, and the sociolinguistic, psycholinguistic aspect, individuality and degree of conformity to conformism language, on the other hand, constitute the elements (indicators) of measuring language inequality.

Language inequality is relative. It is relative, because everyone who writes or speaks, under certain conditions has his own linguistic individuality, has a customized (lexicon) word "confirmed" by others. We always talk to those who have normal language communication conditions.

\section{Conclusion}

When talking about language competence we refer more to Noam Chomsky (Hadson 2002, p. 244.). What is the language competence, referring to the word itself, raises even more the question of what is not the language competence? Lack of language is out of the question. Lack of language may be language inequality.

Lack of language is a kind of language inequality. Language inequality has a wider and multifaceted meaning, with few interpretations. Insufficient reading and lack of speaking activity of individual speaker increases language inequality in relation to those who read, write and speak (interpret and elaborate).

The habit of informal language use do not define all inequality because the same speaker in another circumstance can use the language standard and reach a high degree of linguistic competence. According to this measure, students of Albanian language who in the first year, besides a certain degree of 
language possession in its written and spoken system, also exhibit linguistic inequality.

Language inequality is distinguished both in written discourse and speech discourse. The text sublimates the individual ability and versatility of writing, brainstorming, planning, coherence, and linguistic cohesion. Through the written discourse emerges the language culture of the individual, it is known, depending on the education as a requirement of the education system, dedication and individual sensitivity to the desire to know the language better.

"The same person can use very different linguistic units to express more or less the same meaning in different cases and the concept of dialectically cannot be extended to include such variation" (Hadson, 2002, p. 57.).

Language inequality is relative. It is relative, because everyone who speaks, under certain conditions, has a linguistic individuality of its own. We always talk to those who have normal communication conditions.

The results of this paper reveal student language inequality and the use of standard language in written discourse and speech discourse. They are summarized in these measuring indicators on the written text, reading and interpreting the text on the subject.

\section{References}

1. Baylon Ch. \& Mignot, X., 2004. Komunikimi, Shkup.

2. Dë Sosyr, F., 1977. Kurs i gjuhëssë së përgjithshme, Prishtinë.

3. Grup autorësh, 2002. Gamatika e gjuhës shqipe I, Tiranë.

4. Holmes, J., 2015. Hyrje në sociolinguistikë, Tiranë.

5. Hudson, R. A., 2002. Sociolinguistika, Tiranë.

6. Islamaj, Sh., 2014. Gjuha teksti dhe konteksti, Prishtinë.

7. Ismajli, R., 2003. Standarde dhe identitete, Pejë.

8. Kostallari, A., 1973. Gjuha e sotme letrare shqipe dhe disa problem themelore të drejtshkrimit të saj, Tiranë.

9. Lafe, E., 1983. Rreth normës së sotme në formimin e shumësit të emrave, Probleme aktuale të kulturës së gjuhës shqipe, Prishtinë.

10. Lloshi, Xh., 2012. Stilistika e gjuhës shqipe, Tiranë.

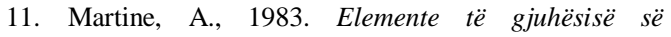
përgjithshme, Prishtinë.

12. Memushaj, R., 2008. Gjuhësia gjenerative, Tiranë.
13. Ndreca, M., 1986. Fjalor fjalësh e shprehjesh të huaja, Prishtinë.

14. Nuhiu, V., 1990. Ndikimet ndërgjuhësore, Prishtinë.

15. Paçarizi, Rr., 2011. Shqipja standarde në parametrat sociolinguistikë, Prishtinë.

16. Ronald, B., 2008. Aventuara semiologjike, Pejë, 2008.

17. Shala, F., 2018. Konformizmi gjuhësor dhe përdorimi i gjuhës standarde, Perla, Tiranë.

18. Shkurtaj, Gj., 2009. Sociolinguistikë e shqipes, Tiranë. 